\title{
Micropropagation of some grape varieties in Kazakhstan
}

\author{
Saule Kazybayeva ${ }^{1 *}$, Irina Kovalchuk ${ }^{1}$, Timur Turdiyev², Shokan Kulshanov ${ }^{3}$ and Laura \\ Azhitayeva ${ }^{1}$ \\ ${ }^{1}$ Limited Liability Company "Kazakh Research Institute of Fruit \& Vegetable Growing”, 238/5 str. \\ Gagarin, Almaty, 050060, Kazakhstan \\ ${ }^{2}$ Republican State Enterprise "Institute of Plant Biology and Biotechnology", 45 str. Timiryazev, \\ Almaty, 050040, Kazakhstan \\ ${ }^{3}$ National Joint Stock Company "Kazakh National Agrarian University", 8 str. Abay, Almaty, 050010, \\ Kazakhstan
}

\begin{abstract}
The article shows the improvement of the process of initiation into in vitro the culture and the clonal micropropagation of grape varieties. The optimal culture media for the initiation and cloning of grapes in vitro have been selected. During initiation on Murashige and Skoog, agar medium with $1 / 2$ or $3 / 4$ concentration of macro- and micronutrients and hormones $(0.5 \mathrm{mg} / 1 \mathrm{BAP}$ and 0.1 $\mathrm{mg} / \mathrm{l} \mathrm{IBA}$ ) is optimal. For micropropagation is suitable MS medium modified by some elements of mineral nutrition: $825 \mathrm{mg} / 1 \mathrm{NH}_{4} \mathrm{NO}_{3}, 166 \mathrm{mg} / \mathrm{l} \mathrm{CaCl} 2,15 \mathrm{mg} / \mathrm{l}$ ferrum chelate; best hormonal composition depends on variety: a) $0.5-1 \mathrm{mg} / \mathrm{l} \mathrm{BAP}$ and $0.1-0.5 \mathrm{mg} / \mathrm{l} \mathrm{IBA}$; b) $0.5 \mathrm{mg} / \mathrm{l} 2-\mathrm{iP}$ and $0.5 \mathrm{mg} / \mathrm{l} \mathrm{GA} 3$.
\end{abstract}

\section{Introduction}

The use of isolated cells in plant breeding in vitro attracts the attention of physiologists, virologists, and, first of all, nurserymen [1]. Micropropagation makes it possible to fully realize the potential of the plant organism [2Nowadays, one of the most promising ways to accelerate the propagation of grape varieties and clones in order to create basic mother plantings of high production categories is micropropagation [3]. Currently, the work on grapes micropropagation is successfully carried out in many scientific and production centers [4]. The reductions in yields due to viruses could reach 50-80\% [5]. Certified young plants that have been cured by the meristem method in vitro should be used to prevent the spread of harmful diseases during the planting. $[6,7]$. The advantage of in vitro technique is obtaining a genetically homogeneous, virus tested stem cuttings of grapes using the latest methods of biotechnology $[8,9,10,11]$.

The published works reflect the results of numerous studies in the field of micropropagation of grapes, but a number of researchers note that the propagation of plants in vitro depends on the individual characteristics of the variety $[12,13,14,15]$. The grape varieties with a number of economically valuable characteristics have been bred in Kazakhstan, and they need accelerated propagation and obtaining certified planting material. This research focused on improving

\footnotetext{
*Correspondingauthor: Saule 567@,mail.ru
} 
micropropagation of some domestic and introduced grape varieties in the production system of highquality planting material.

\section{Materials and Methods}

The studying objects were prospective and comprehensively resistant grape varieties (domestic and introduced): Botagoz, Akmaral, Aisulu, Kara Koz, Kyzyl tan, Skorospely, Early Kibrajskii.

Methodology of the study conforms currently accepted requirements. Isolated explants were disinfected from saprophytic microflora and were introduced into culture medium. The conditions for tissue disinfection and the composition of culture medium that contribute to the initiation of shoot growth, proliferation and root formation in vitro were optimized. On the basis of Murashige and Skoog medium were tested different variants of agar medium that differ in the concentration of mineral elements and hormonal composition. Following plant growth regulators were checked: 6-benzylaminopurine (BAP), 6- $\gamma-\gamma$-(dimethylallylamino)-purine (2-iP), thidiazuron (TDZ), indole-3-butyric acid (IBA), 1-naphthaleneacetic acid (NAA), indole-3-aceticacid (IAA), 6Furfurylaminopurine (kinetin), zeatin and gibberellicacid $\left(\mathrm{GA}_{3}\right)$ in different concentration. Cultivation of plant material was carried out in culture vessels. The passage of explants was carried out as necessary.

\section{Results and Discussion}

The selection of disinfection agents against the saprophytic microflora on stem segments with apical and lateral grape buds showed that effective methods of sanification are: a) $\mathrm{HgCl}_{2} 0,2 \%$ in 5 min exposure; б) $\mathrm{HgCl}_{2}$ 0,1\% - 4 min, after $\mathrm{KMnO} 4$ - $10 \mathrm{~min}$; в) household detergent «Domestos» 1:5 - 5 min. The best disinfection agent was $\mathrm{HgCl}_{2}$. However, this mercuriferous agent could be successfully replaced by less dangerous chloriniferous "Domestos"; efficacy of this household detergent applied as disinfection agent is $65-85 \%$. To select the optimal culture medium in vitro culture of grapes, various growth regulators and their concentrations were tested (on the MS medium with a full or partial concentration of salts) (Fig.1).

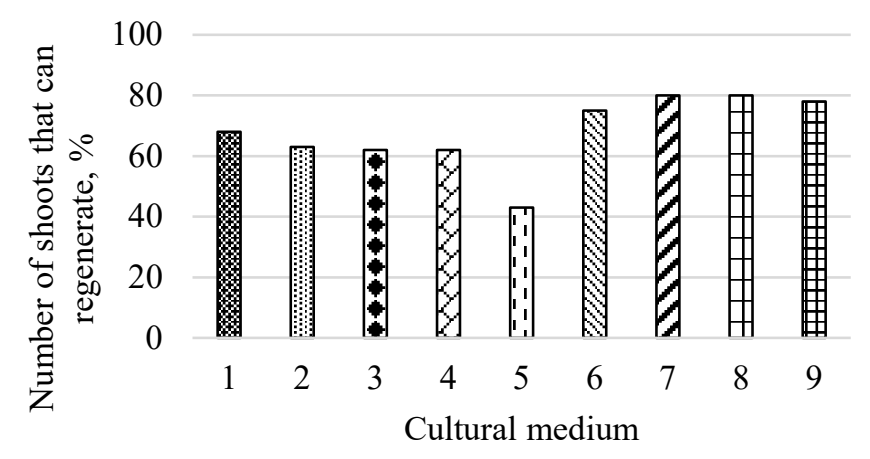

*1. MS, BAP - 1.0, IBA - 0.2, GA 3 - 1.0;

2. MS, BAP - 1.0, IBA - 0.2;

3. MS, BAP - 1.5, IBA - 0.1;

4. MS, BAP - 2.0, IBA - 0.5;

5. $\mathrm{MS}, \mathrm{GA}_{3}-2.0$

6. $1 / 2$ MS, BAP -0.1, IBA - 0.1;

Polyvinylpyrrolidone - 25,0;

7. $1 / 2 \mathrm{MS}$, BAP - 0.5 , IBA - 0.1, glucose - $20 \mathrm{~g} / \mathrm{l}$;

8. $3 / 4$ MS, BAP -0.5 , IBA - 0.1;

9. $1 / 2 \mathrm{MS}, \mathrm{BAP}-1.0, \mathrm{IBA}-0.2$

Fig. 1. Influence of culture medium composition on the initiation of grape shoot growth in vitro (average value for following varieties: Akmaral, Aisulu, Skorospely), mg/l 
It was found that growth stimulants have a positive effect on the regeneration of shoots introduced in vitro. The regeneration of shoots decreased if medium did not contain cytokinins and auxins. The presence of gibberellic acid in the culture medium did not affect the induction of growth and development of lateral buds, but stimulated the pulling of shoots.

The average data for the three studied varieties showed that agar culture media with $1 / 2$ or $3 / 4$ concentration of macro- and micronutrients, hormones - 0.5-1.0 mg/1 BAP and 0.1-0.2 mg/l IBA, $30 \mathrm{mg} / 1$ sucrose or $20 \mathrm{~g} / 1$ glucose were optimal for the grape's introduction to in vitro culture. The screening of 7 varieties on MS medium containing $1.0 \mathrm{mg} / \mathrm{l} \mathrm{BAP}$ and $0.5 \mathrm{mg} / \mathrm{l} \mathrm{IAA}$ showed genotypic specificity of grape plant development, i.e. the potential for micropropagation depended on the grape variety. The best result of propagation on the culture medium were showed Botagoz, Aisulu, Skorospely, Kara Koz varieties. The average reproduction rate for the $1^{\text {st }}$ passage was 3.0; 2.7; 3.0, respectively. The variety Kyzyl Tan had reproduction coefficient 1.3 - it was the worst result of propagation.

The experiments of grapes micropropagation was on MS culture medium. The various number of concentrations of the mineral base of the MS medium were tested on the Botagoz, Aisulu and Skorospely varieties. The hormonal base of all variants was identical and consisted of $0.5 \mathrm{mg} / \mathrm{l}$ BAP and $0.1 \mathrm{mg} / 1 \mathrm{IBA}$. As the result was identified that following culture medium for grapes micropropagation are optimal: 1) Medium 1 - modified MS medium, containing $825 \mathrm{mg} / \mathrm{l} \mathrm{NH}_{4} \mathrm{NO}_{3}$, $166 \mathrm{mg} / \mathrm{l} \mathrm{CaCl}_{2}, 15 \mathrm{mg} / \mathrm{l}$ ferrum chelate; 2) Medium 2 - modified MS medium with $1 / 2$ concentration of macro- and micronutrients (fig. 2).
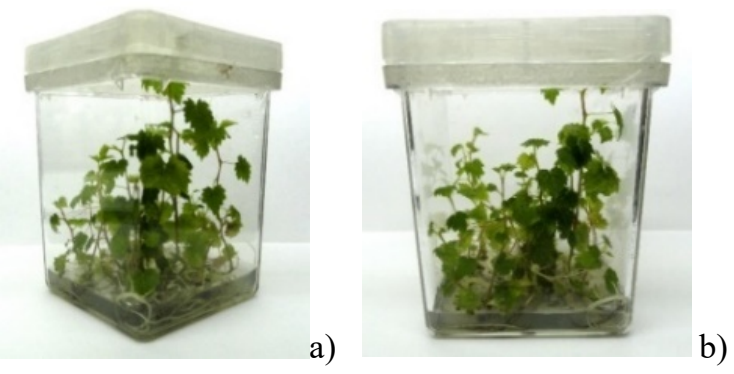

Fig. 2. Micropropagation of grapes on modified MS medium culture in vitro, containing $825 \mathrm{mg} / 1$ $\mathrm{NH}_{4} \mathrm{NO}_{3}, 166 \mathrm{mg} / 1 \mathrm{CaCl}_{2}, 15 \mathrm{mg} / 1$ ferrum chelate a) Aisulu variety; b) Skorospely variety.

Effect of the medium hormonal composition (BAP, IBA, IAA, GA $\mathrm{G}_{3}$ ) on micropropagation was studied. The first set of experiments was conducted on the base of full or $1 / 2$ salts concentration of MS medium (Fig. 3).

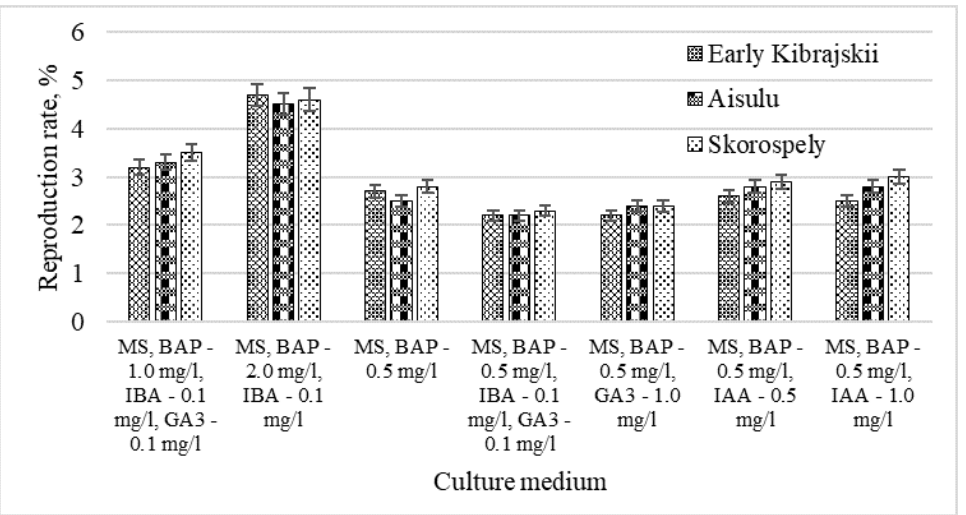

Fig. 3. Effect of the medium hormonal composition (BAP, IBA, IAA, GA3) on grapes micropropagation in vitro culture on the base of the full salts concentration of MS medium. 
It was found, that growth stimulants have a positive effect on the formation of additional shoots during micropropagation in vitro. The increase of BAP concentration to $2 \mathrm{mg} / \mathrm{l}$ in the culture medium contributed to increase in the number of formed shoots, but led to the formation of callus. The presence of auxins - IBA or IAA, positively affected the propagation of shoots, but there was no significant difference in the increase in shoot formation between them. On the MS medium containing $1.0 \mathrm{mg} / \mathrm{l} \mathrm{GA}_{3}$ and $0.5 \mathrm{mg} / \mathrm{l} \mathrm{BAP}$, plants reached a length of $4-5 \mathrm{~cm}$ and were suitable for micro-shoots propagation.

Due to the fact that the results of experiments on testing various concentrations of the mineral base of the MS medium showed that the media with $1 / 2$ concentration of macro- and microelements are optimal for the clonal micropropagation of grapes, we conducted a second series of experiments to establish the optimal hormonal composition (BAP, kinetin, zeatin, TDZ, 2-iP, IBA, NAA, IAA) based on the $1 / 2$ concentration of MS medium. The results are shown in the fig. 4 .

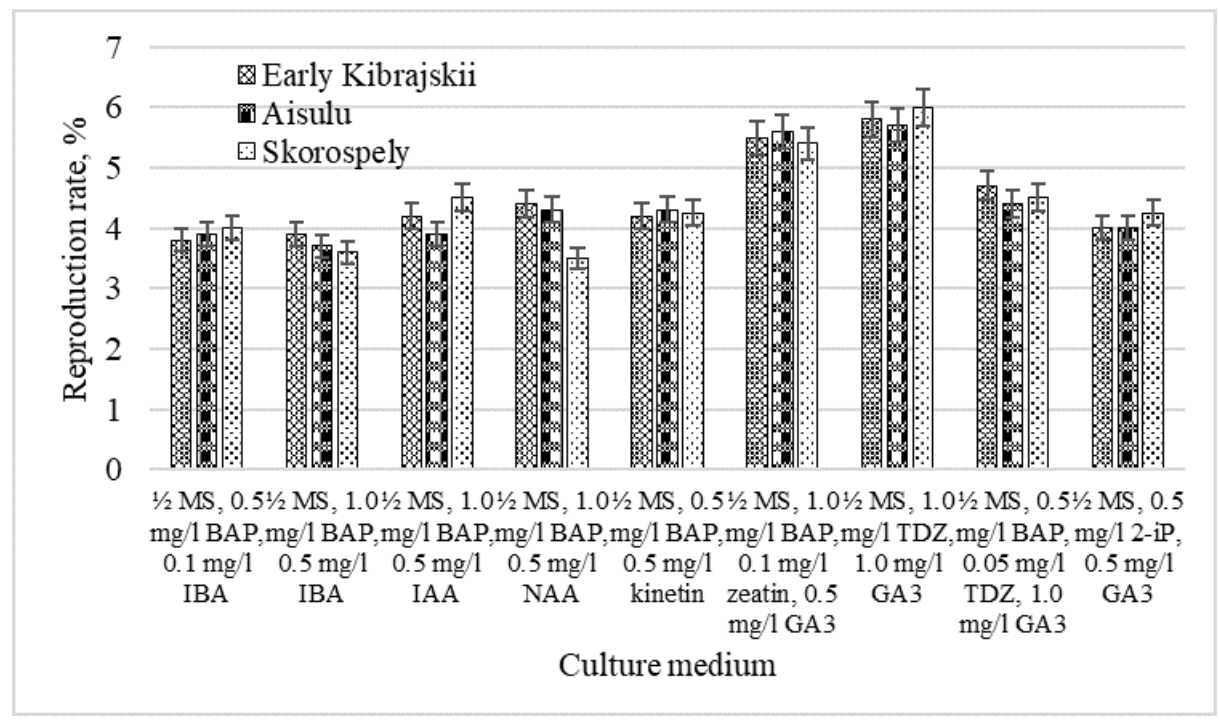

Fig. 4. Effect of the medium hormonal composition (BAP, kinetin, zeatin, TDZ, 2-iP, IBA, NAA, IAA) on grapes micropropagation on the $1 / 2$ concentration of MS medium.

The results showed that the highest reproduction rate of shoots was observed on $1 / 2$ concentration of the MS medium containing $1.0 \mathrm{mg} / \mathrm{l} \mathrm{TDZ}$ in combination with $1.0 \mathrm{mg} / \mathrm{l} \mathrm{GA}_{3}$ (RR 5,8-6,0), as well as on $1 / 2$ concentration of the MS medium with $1.0 \mathrm{mg} / \mathrm{l}$ BAP in combination with $0.1 \mathrm{mg} / \mathrm{l}$ zeatin and $0.5 \mathrm{mg} / \mathrm{l} \mathrm{GA} 3$ (RR 5,4-5,7). However, in both variants, the quality of adventitious shoots was unsatisfactory. They were shortened (despite the presence of $\mathrm{GA}_{3}$ in the first case), thickened, and at the base of the shoots formed a callus. Kinetin had almost no effect on the induction of growth and development of shoots in the studied concentrations. The good quality of adventitious shoots was on $1 / 2$ concentration of the MS medium containing 0.5-1 mg/1 BAP combined with 0.1-0.5 mg/ IBA and on $1 / 2$ concentration of the MS medium with $0.5 \mathrm{mg} / 12$-iP combined with $0.5 \mathrm{mg} / \mathrm{l} \mathrm{GA}_{3}$. Callus formation was observed on MS medium with the addition of $0.5 \mathrm{mg} / 1 \mathrm{NAA}$. At the rooting stage, micro-shoots of grapes 20-30 mm high with 2-3 nodes were planted щт the MS culture medium containing half the amount of macro-and microsalts, a full set of vitamins $0.5 \mathrm{mg} / \mathrm{l}$ each and $1.0 \mathrm{mg} / \mathrm{l} \mathrm{IBA}$. In this medium, the initiation of rhizogenesis was quite high and varied depending on the genotype from 85 to $95 \%$. Already on the 15 th day of cultivation, the formation of 1-3 roots with a length of $5 \mathrm{~mm}$ in the basal part of the microshoots was noted. In the future, there was a gradual increase in their number and length. Thereafter was a gradual increase in their number and length. In the Aisulu variety, the total root length was $25 \mathrm{~mm}$, in the Skorospely variety $-35 \mathrm{~mm}$, in the Early Kibrajskii 
variety $-29 \mathrm{~mm}$. The formation of roots in the selected medium for all varieties was stable and did not require additional experiments.

\section{Conclusion}

Grapes explants can be effectively disinfected from saprophytic microflora in one of the following ways: a) $\mathrm{HgCl}_{2}$ 0,2\% in 5 min exposure; б) $\mathrm{HgCl}_{2}$ 0,1 \% - 4 min, after $\mathrm{KMnO} 4$ - $10 \mathrm{~min}$; в) «Domestos» 1:5 - 5 min. The optimal agar medium for introduction containing $1 / 2$ or $3 / 4$ concentrations of macro-and micronutrients according to the MS and following hormones $-0.5 \mathrm{mg} / \mathrm{l}$ BAP, $0.1 \mathrm{mg} / \mathrm{l} \mathrm{IBA}$. The MS medium modified for some components of mineral nutrition is effective: $825 \mathrm{mg} / 1 \mathrm{NH}_{4} \mathrm{NO}_{3}, 166 \mathrm{mg} / \mathrm{CaCl}_{2}, 15 \mathrm{mg} / \mathrm{l}$ ferrum chelate, the best hormonal composition depends on the variety: a) $0.5-1 \mathrm{mg} / \mathrm{l} \mathrm{BAP}$ and $0.1-0.5 \mathrm{mg} / \mathrm{lBA}$ or b) $0.5 \mathrm{mg} / 12$-iP and $0.5 \mathrm{mg} / \mathrm{GA}_{3}$. Rhizogenesis of aseptic plants in vitro effectively occurs on agar medium MS, containing $1 / 2$ concentration of macro-and micronutrients, a full set of vitamins $0.5 \mathrm{mg} / \mathrm{l}$ each and auxin $-1.0 \mathrm{mg} / \mathrm{l} \mathrm{IBA}$.

\section{References}

1. A. Rakhimzhanov, S. Zalesov. Agriculture, 4(82), 130-135 (2019). https://doi.org/10.23670/IRJ.2019.82.4.027

2. S. Jayakumsr, R. Ramalinagam. Not Sci Biol., 5(3), 338-345 (2013). https://www.researchgate.net/publication/307699572

3. C. F. Popescu, E. Maul, L. C. Dejeu, D. Dinu, R. N. Gheorge, V. Laucou, T. Lacombe, $\begin{array}{lllll}\text { D. Migliaro, M. } & \text { Crespan, } & \text { Vitis, } & \text { 56(4), } & \text { 173-180 }\end{array}$ https://doi.org/10.5073/vitis.2017.56.173-180

4. F. K. Pilatti, T. Aguiar, T. Simões, E. E. Benson, A. M. Viana, In Vitro Cell.Dev.Biol.Plant, 47, 82-98 (2011). https://doi.org/10.1007/s11627-010-9302-y

5. N. Arismendi, N. Andrade, R. Riegel, R. Carrillo, Chilean J. Agric. Res., 70(1), 26-33 (2010). http://dx.doi.org/10.4067/S0718-58392010000100003

6. B. Duduk, A. Bertaccini. Phytopathogenic Mollicutes, 1(1), 3-13, http://doi.org/10.5958/J.2249-4669.1.1.001

7. E. A. Egorov, L. L. Buntsevich, Horticulture and viticulture, 2, 39-42 (2018). https://doi.org/10.25556/VSTISP.2018.2.12305

8. M. Pingel, A. Reineke, I. Leyer, Agric. Ecosyst. Environ., 272, 114-125 (2019). https://doi.org/10.1016/j.agee.2018.11.005

9. M. A. Ramírez-Mosqueda, C. A. Cruz-Cruz, J. Atlahua-Temoxtle, J.J. Bello-Bello, S. African J. Bot., 121, 219-223 (2019). http://doi.org/10.1016/j.sajb.2018.11.010

10. T. S. Pedro, R. Peiro, J. Villanova, A. Olmosand, C. Gisbert, Electron J. Biotechn., 27, 80-83 (2017). http://doi.org/10.1016/j.ejbt.2017.03.006

11. S. A. M. Hassan, N.S. Zayed, Science International, 6(1), 1-10 (2018). http://doi.org/10.17311/sciintl.2018.1.10

12. C. A. Cruz-Cruz, M.T. Gonzalez-Arnao, F. Engelmann, Resources, 2(2), 73-95 (2013). http://doi.org/10.3390/resources2020073

13. D. Dal Bosco, I. Sinski, V. Comachio, J. D. G. Maia, P. S. Ritschel, V. Quecini, ActaHortic., 1082, 201-205 (2015). https://doi.org/10.17660/ActaHortic.2015.1082.27

14. J. C. Bettoni, R. Bonnart, A. Shepherd, A. A. Kretzschmar, G. M. Volk, Vitis, 58(2), 7178 (2019). https://doi.org/10.5073/vitis.2019.58.71-78

15. M. Alizadeh, S. K. Singh, V. B. Patel, Int. J. Plant Prod., 4(1), 41-50 (2010). https://www.researchgate.net/publication/228618108 